\title{
THE FEDERAL RULES OF CIVIL PROCEDURE IN THE CONTEXT OF TRANSNATIONAL LAW
}

\author{
GEORGE K. WALKER*
}

\section{INTRODUCTION}

\begin{abstract}
Application of international law to civil litigation in the transnational context ${ }^{1}$ can have some of the attributes of matryoshki, the Russian "oneinside-the-other wooden dolls, shaped like bowling pins, with a vacant "happy face' on each." 2 The litigator is invited onward through the collection, only to arrive at a final doll with an equally enigmatic smile, no clear-cut answers, and perhaps a feeling that the process is posh $i^{3}$ after all. Give us some straightforward rules, the barristers say. The rules drafters have been at work. ${ }^{4}$
\end{abstract}

Copyright (C) 1994 by Law and Contemporary Problems

* Professor of Law, Wake Forest University. Professor Walker is Reporter for the U.S. District Court for the Middle District of North Carolina Advisory Group for implementation of the Civil Justice Reform Act of 1990 and was Charles H. Stockton Professor of International Law at the Naval War College when this article was delivered as a paper. Views expressed here are the author's and do not express the official policy or position of the U.S. courts, the Department of Defense, or the U.S. Government.

1. Philip C. Jessup, Transnational Law 2 (1956) coined the phrase "transnational law."

2. Steven Erlanger, Moscow Journal: Where Tourists Rummage in Communism's Attic, N.Y. Times, Sept. 21, 1992, at A4. Carol Kramer, Odd Birds in the Nest, N.Y. TimeS, Mar. 7, 1993, § 9, at 10 , suggests that the nesting dolls are of Chinese origin.

3. Perhaps untranslatable: "It encompases banality, triviality and kitsch, with a crucial added dash of vulgarity." Erlanger, supra note 2; see LOUIS SEGAL, NEW COMPLETE RUSSIAN-ENGLiSH DICTIONARY 618 (1959).

4. Extensive amendments to FED. R. CIV. P. 4, 12, 26, and 28, deletion of Forms relating to discovery and service of process in the international context, and new Rule 4.1 and Forms $1 \mathrm{~A}$ and $1 \mathrm{~B}$ were submitted to the Supreme Court of the United States in 1989. See Committee on Rules of Practice and Procedure of the Judicial Conference of the United States, Preliminary Draft of Proposed Amendments to the Federal Rules of Appellate Procedure and the Federal Rules of Civil Procedure (Sept. 1989), 127 F.R.D. 237, 266-301, 305-07, 317-23, 397-403 (1990) [hereinafter Preliminary Draft]. While the rules were pending before the Court, the Department of Justice and the Department of State warned that to avoid possible offense to other governments, Rule 4(d)'s request for waiver procedures should be limited to defendants located within the United States. Letter from U.S. District Judge Sam C. Pointer, Jr., chair of the Advisory Committee on Civil Rules, to U.S. District Judge Robert E. Keeton (May 1, 1992) [hereinafter Pointer Letter], Attachment B, at 1, reprinted in Amendments to Federal Rules of Civil Procedure [hereinafter Amendments], 146 F.R.D. 401, 521 (1993) (except Attachment A, which is on file with author); see also Stephen B. Burbank, The World in Our Courts, 89 MICH. L. REV. 1456, 1484-85 nn.160-68 (1991), reviewing GARY B. BORN \& DAVID WESTIN, INTERNATIONAL CIVIL LITIGATION IN UNITED STATES COURTS: COMMENTARY AND MATERIALS (1989). The Supreme Court linked the Rule 12(a) amendment to the Rule 4 proposal and returned both for further study. Pointer Letter, supra, Attachment B, at 6, reprinted in Amendments, 146 F.R.D. at 526. The Court also returned a proposed change of Rule 26(a) concerning regulation of discovery in foreign countries and amendments to Rule $28(\mathrm{~b})$, which governs foreign-country depositions. Id. at 8-9, reprinted in Amendments, 146 F.R.D. at 528-29. Additional proposed amendments were published in August 1991, but these are not relevant to this analysis. See Committee on Rules of 
Analytically, the problem of the place of the Federal Rules of Civil Procedure in the context of international law may also be seen as a multilayer Venn Diagram, since those contemplating the use of the Rules in an international context must consider several interacting bodies of law, including U.S. legislation, public international law, and concepts such as comity. ${ }^{5}$. Three recent proposals for amendments to the Federal Rules of Civil Procedure illustrate the problem:

1. the waiver of service costs provisions for Rule 4, which apply only to parties in the United States; however, the version approved by the Advisory Committee on the Civil Rules would have permitted such costs to be assessed unless a foreign nation prohibited waivers of service; ${ }^{6}$

Practice and Procedure of the Judicial Conference of the United States, Preliminary Draft of Proposed Amendments to the Federal Rules of Civil Procedure and the Federal Rules of Evidence (Aug. 1991), 137 F.R.D. 53 (1991). On May 1, 1992, the Advisory Committee on the Civil Rules submitted proposals for amending Rules 4, 12(a), 26(a)(5), and 28(b) to the Standing Committee on Rules of Practice and Procedure. Pointer letter, supra, Attachment B, at 1, 6, 8, 9, 146 F.R.D. at 521, 526, 528-29. On November 27, 1992, the Judicial Conference of the United States submitted its proposals for amending these rules to the Supreme Court of the United States. Judicial Conference of the United States, Proposed Amendments to the Federal Rules of Civil Procedure and Forms 1-40, 59-61, 72-78, 104, 111-13 (Nov. 1992), reprinted in Amendments, supra, 146 F.R.D. at 535-74, 593-95, 606-12, 645-47. On April 22,1993 , the Supreme Court of the United States submitted the proposed rules to Congress. Letter of Chief Justice William H. Rehnquist to Speaker of the House Thomas Foley (Apr. 22, 1993), reprinted in Amendments, supra, 146 F.R.D. at 403. Three justices (Scalia, Thomas, and Souter) dissented from the revisions regarding Rule 11 sanctions. Amendments, supra, 146 F.R.D. at 507-13.

The 1993 proposals, particularly the Rule 26 amendment requiring automatic disclosure of certain information during the discovery process, excited controversy in Congress, within the bar, and among commentators. See, e.g., Griffin B. Bell, et al., Automatic Disclosure in Discovery-the Rush to Reform, 27 GA. L. REv. 1 (1993); Paul R. Sugarman \& Marc G. Perlin, Proposed Changes to Discovery Rules in Aid of "Tort Reform": Has the Case Been Made?, 42 AM. U. L. REV. 1465 (1993); Ralph K. Winter, In Defense of Discovery Reform, 58 BROOK. L. REV. 263 (1992). H.R. 2814, 103d Congress, 1st Sess. (1993) would have deleted the change in disclosure requirements and would have made other changes to the Rule 30,31, and 33 proposals. The U.S. Department of Justice reversed its position under the Bush Administration by dropping its opposition to the revised disclosure procedure. Rhonda McMillion, Whoa!, A.B.A. J., Sept. 1993, at 119. Commentators urged selective approval of the 1993 rules package. See, e.g., Carl Tobias, Congress and the 1993 Civil Rules Proposals, 148 F.R.D. 383 (1993). However, Congress adjourned without passing any legislation on the subject. H.R. 2814 mired down in the Senate over the Rule 30,31, and 33 proposals. Civil Discovery Bill Bogs Down: Revised Rules Take Effect Dec. 1, 1993 Daily Rep. for Executives (BNA) 225 (Nov. 24, 1993). The amendments became effective on December 1, 1993. Richard B. Schmitt, New Rules to Take Effect, WALL ST. J., Nov. 29, 1993, at B5. Opponents of the Rules stated that it would be likely that Congress would modify the rules when it reconvenes in 1994. Id.

By contrast, the proposals for FED. R. CIV. P. 44(a)(2), relating to certification of official records as permitted by the Convention Abolishing the Requirement of Legalization for Foreign Public Documents, Oct. 5, 1961, 33 U.S.T. 883, 527 U.N.T.S. 189, sailed through the amendment process. Compare Preliminary Draft, supra, at 338-40, with FED. R. CIV. P. 44(a)(2).

5. For an example of Venn Diagram analysis in the context of another kind of rules-the Rules of Engagement for military operations, see J. Ashley Roach, Rules of Engagement, 14 SYRACUSE J. INT'L L. \& COM. 865, 866-67 (1988), reprinted from 36 NAVAL WAR COLL. REV., Jan.-Feb. 1983, at 46, 47-48; see also BRADD C. HAYES, NAVAl RULES OF ENGAGEMENT: MANAGEMENT TOOLS For CRISIS 8, 13 (Rand Report No. N-2963-CC 1989).

6. Pointer letter, supra note 4, Attachment A at 5-7, 17-21; Attachment B at 1, 146 F.R.D. at 521. 
2. the foreign-country discovery provisions of Proposed Rule 26(a)(5), suggested by the Advisory Committee but deleted by the Standing Committee on Rules of Practice and Procedure; ${ }^{7}$ and

3. the foreign-country depositions provisions of Proposed Rule 28(b), originally tied to the Rule 4 proposals of 1989 , which have gone forward to the Supreme Court for possible approval. ${ }^{8}$

The central theme of this article is the development of exceptions in the Rules of Civil Procedure and federal statutes that apply only to litigants outside the United States. The article's thesis is that the Rules should not make exceptions on a blanket basis, as some recent proposals would have it. Congress, not the Supreme Court, should be the agent for change in this sensitive area of litigation, so potentially charged with foreign policy implications.

Part II of the analysis that follows considers the jurisprudential uncertainties present in all U.S-based transnational civil litigation. Part III focuses on current examples from civil litigation where procedural norms favor one party over another, for policy reasons, or where all parties have no special dispensation or advantage. Part IV traces the history of proposed amendments, most of them now discarded, to Federal Rules of Civil Procedure 4, 26, and 28. Part V recommends that the Rules should not include an automatic advantage to foreign litigants and that any foreign claims for dispensation should be subject to a factor-balancing analysis similar to that articulated in the Restatement (Third) of Foreign Relations Law (1987), ${ }^{9}$ at least until Congress provides further guidance.

\section{II}

\section{JURISPRUDENTIAL UNDERPINNINGS}

The relative uncertainty in transnational litigation and in application of procedural principles and rules to assure fundamental fairness to all parties can be traced to the multilayer, multifactor processes of analysis that are at work in such cases. This section discusses some of the more important factors that may be involved in any case of transnational litigation.

There is no international consensus concerning the relative importance of the various sources of international law. First, although some commentators may accord more or less primacy to one source or another,,$^{10}$ most would say that

7. Id., Attachment $\mathrm{A}$ at 54, 70-71; Attachment B at 8, 146 F.R.D. at 528.

8. Id., Attachment A at 77-78; Attachment B at 9,146 F.R.D. at 529 (referring to Preliminary Draft, supra note 4 , at 321-23).

9. See infra notes 63-71 and accompanying text.

10. See, e.g., IAN Sinclair, The Vienna Convention On The Law Of Treaties 2 (2d ed. 1984) (treaties of greater importance than custom); but see his later thoughts, id. at 252-58; RESTATEMENT (THIRD) OF FOREIGN RELATIONS LAW OF THE UNITED STATES $\S \S 102(1)(c), 102(4) \&$ r.n. 7 (1987) [hereinafter RESTATEMENT (THIRD)](general principles a secondary or supplementary source to a primary source such as custom); GERHARD VON GLAHN, THE LAW AMONG NATIONS 23 (5th ed. 1986) (most authors consider general principles a subsidiary source); G.I. TUNKIN, THEORY OF INTERNATIONAL LAW 133 (William E. Butler trans. 1974) (Soviet view of treaties as dominant source for development of international law); R.R. Baxter, Treaties and Custom, 129 RECUIEL DES CouRs 25, 96- 
there are three principal sources of international law: treaties between or among the parties; custom, that is, state practice accepted as law; and general principles of law. ${ }^{11}$ Secondary sources include judicial decisions, the writings of scholars, and law-declaring resolutions of international organizations. ${ }^{12}$ By contrast, U.S. courts follow a hierarchical pattern:

International law is part of our law, and must be ascertained and administered by the courts of justice of appropriate jurisdiction, as often as questions of right depending upon it are duly presented for their determination. For this purpose, where there is no treaty, and no controlling executive or legislative act or judicial decision, resort must be had to the customs and usages of civilized nations; and, as evidence of these, to the works of jurists and commentators, who by years of labor, research and experience, have made themselves peculiarly well acquainted with the subjects of which they treat. Such works are resorted to by judicial tribunals, not for the speculations of their authors concerning what the law ought to be, but for trustworthy evidence of what the law really is. ${ }^{13}$

That international law is part of U.S. domestic law is well known; Habana's analysis of customary law is also well known. ${ }^{14}$ The opportunity for application of customary principles can occur only in the absence of U.S. court precedent, executive proclamation or agreement, congressional legislation, or treaties. U.S. federal and state ${ }^{15}$ courts have little opportunity for judicial creativity through custom or general principles of law as compared to courts outside the United States, since they must apply federal statutes, treaties, or executive pronouncements under a later-in-time principle. ${ }^{16}$ Federal statutes preempt any federal common law. ${ }^{17}$ And although there have been intimations that a later-

97 (1970) (treaties can interfere with development of customary law).

11. STATUTE OF THE INTERNATIONAl COURT OF Justice, June 26, 1945, art. 38, 59 Stat. 1031, 1065, 3 Bevans 1153, 1187 [hereinafter ICJ STATUTE], states the formula that must be applied in litigation before the International Court of Justice and which has supplied the traditional mode of analysis; see also supra note 10, particularly RESTATEMENT (THIRD) $\$ \S 102-103$, which supply variants on the theme. When "state" is used in this article, I refer to entities that are nation-states in the sense of $i d . \S 201$. When "State" is used, the reference is to one of the 50 States of the United States.

12. Compare ICJ STATUTE, supra note 11, art. 38, para. 1(d) (listing the first two as secondary sources) with RESTATEMENT (THIRD), supra note $10, \S 102$ r.n. $1, \S 103$ (treating all three as "evidence" of the law).

13. The Paquete Habana, 175 U.S. 677, 700 (1900) (citing Hilton v. Guyot, 159 U.S. 113, 163, 164, 214, 215 (1895)). But see RESTATEMENT (THIRD), supra note 10, \$§ 102, 112.

14. Habana, 175 U.S. at 686-96. For a recent analysis in the context of modern sources for custom, see Filartiga v. Pena-Irala, 630 F.2d 876 (2d Cir. 1980). Tel-Oren v. Libyan Arab Republic, 517 F. Supp. 542 (D.D.C. 1981), aff'd per curiam, 726 F.2d 774 (D.C. Cir. 1984), cert. denied, 470 U.S. 1003 (1985), decided the merits differently.

15. The state courts must follow federal common law as well as the national courts. Free v. Bland, 369 U.S. 663, 666-70 (1962); RESTATEMENT (THIRD), supra note 10, \$111 cmt. d \& r.n. 3 (federal court interpretation of customary international law binding on state courts).

16. U.S. CONST. art. VI; Whitney v. Robertson, 124 U.S. 190, 193-95 (1888); RESTATEMENT (THIRD), supra note $10, \S 115$. However, if a federal statute and an international agreement can be fairly construed so as not to conflict, the court should give effect to both. Trans World Airlines v. Franklin Mint Corp., 466 U.S. 243, 252-53 (1984); United States v. Palestine Liberation Org., 695 F. Supp. 1456, 1465 (S.D.N.Y. 1988); RESTATEMENT (THIRD), supra note 10, 1114 . As the Habana court predicted, federal legislation later in time supersedes custom in the courts of the United States to the extent of any inconsistency between the two sources. See, e.g., United States v. Yunis, 924 F.2d 1086, 1091 (D.C. Cir. 1991).

17. Middlesex County Sewerage Auth. v. National Sea Clammers Ass'n, 453 U.S. 1, 21-22 (1981) (citing Milwaukee v. Illinois, 451 U.S. 304 (1981), which distinguished Illinois v. Milwaukee, 406 U.S. 
developed custom appearing in U.S. jurisprudence as federal common law can supersede an international agreement, ${ }^{18}$ the orthodox view is that treaties are paramount and stand, regardless of their age. ${ }^{19}$

Second, there is disagreement concerning the weight that should be afforded to international law relative to municipal (national) law. Many nations observe the dualist theory of international law, under which conflicts between international law and municipal law would be resolved in favor of the latter. Other nations abide by the monist theory, which holds that international law "as the best available moderator of human affairs" would be supreme over national law. ${ }^{20}$ Although the Habana ${ }^{21}$ statement and the Constitution's Supremacy Clause $^{22}$ would seem to place the United States in the monist camp, in fact the reverse is true. The later-in-time rule, even as applied to United Nations

91 (1972), because of intervening federal preemptive legislation).

18. RESTATEMENT (THIRD), supra note $10, \S 115 \mathrm{cmt}$. d \& r.n. 4, says that there have been no cases on whether a newly developed custom could supersede U.S. treaty law; see the Restatement's Chief Reporter, Louis Henkin, The Constitution and United States Sovereignty: A Century of Chinese Exclusion and its Progeny, 100 HARV. L. REV. 853, 877-78 (1987); Louis Henkin, International Law as Law in the United States, 82 MICH. L. REV. 1555, $1561-67$ (1984) (expanding on the Restatement analysis); see also LoUIS HENKIN, FOREIGN AFFAIRS AND THE CONSTITUTION 163-64 (1972) (relative - weight of statutes versus treaties).

19. Robert E. Dalton, International Agreements in the Revised Restatement, 25 VA. J. INT'L L. 153, 157-59 (1984); Panel, The Revised Draft Restatement of the Foreign Relations Law of the United States and Customary International Law, 1985 PROC. AM. SOC'Y INT'L L. 73-76 (1987) (remarks by Jack M. Goldklang); see also Cannon v. United States Dep't of Justice, U.S. Parole Comm'n, 973 F.2d 1190, 1192 (5th Cir. 1992), which cites the Supremacy Clause, U.S. ConST. art. VI, in the context of a treaty, federal legislation, and the sentencing guidelines.

There are established doctrines in international law, not applied in the United States, under which the opposite result could obtain. RESTATEMENT (THIRD), supra note $10, \S 102 \mathrm{cmt}$. j \& r.nn. 1,4 (citing, inter alia, ICJ STATUTE, supra note 11, art. 38(1), and RESTATEMENT (THIRD), supra, note 10, $\$ 514$ ) (noting that nearly universal claims for 200-mile exclusive economic zones superseded the 1958 Law of the Sea Conventions). Some doctrines of the law of treaties, such as desuetude, or the principle that relatively ancient treaties have become meaningless, might assist in the argument. IAN BROWNLIE, PRINCIPLES OF PUBLIC INTERNATIONAL LAW 617-18 (4th ed. 1990). Lord McNair would argue against willy-nilly application of these principles, and both note the strength of the principle of pacta sunt servanda. LORD MCNAIR, THE LAW OF TREATIES 493-505, 516-18 (1961); BROWNLIE, supra at 616; see also Vienna Convention on the Law of Treaties, May 23, 1968, art. 25, 1155 U.N.T.S. 331, 339; RESTATEMENT (THIRD), supra note $10, \S 321 \mathrm{cmt}$. a (noting that the pacta sunt servanda doctrine "lies at the core of the law of international agreements and is perhaps the most important principle of international law"). Id., Part III, Introductory Note, at $144-45$, notes that although the United States has not ratified the Convention, the Department of State generally recognizes it as the authoritative guide to current treaty law and practice. The United States is party to several treaties that restate the pacta principle. See, e.g., U.N. CHARTER, preamble, art. 2, If 2; CHARTER OF THE ORGANIZATION OF AMERICAN STATES art. 14 [hereinafter OAS CHARTER]. Moreover, arguments based on desuetude or similar theories might not be available in U.S. courts unless the United States has expressed such a view on the international plane. Cf. Trans World Airlines v. Franklin Mint, 466 U.S. 243, 253 (1984) (fundamental change of circumstances not available to private litigant unless its government has invoked it).

20. BROWNLIE, supra note 19 , at 32-33.

21. 175 U.S. 677,700 (1900).

22. U.S. CoNST, art. VI. 
Security Council decisions $\mathrm{s}^{23}$ conflicting with later federal legislation, ${ }^{24}$ ensures the ultimate authority of federal laws in the United States.

Additional problem areas involving the application of transnational law to U.S.-based civil litigation lie within the federal courts system and the courts of the fifty states. For example, if a treaty regulating civil procedure requires implementing legislation, ${ }^{25}$ then the litigant must look to the legislation for the scope of procedural rights. ${ }^{26}$ If a federal statute purports to regulate procedure

23. The U.N. Charter arts. 25,48 , parts of a treaty in force in the United States, 59 Stat. 1031 (1945), declare that all U.N. members will carry out decisions of the U.N. Security Council. In effect, this delegation is of national sovereignty by treaty to an international executive or administrative body. This procedure was evident in the 1990-91 Gulf War, whose outcome is still governed by Security Council decisions. For analysis of Council decisions in the War, see, e.g., Christopher Greenwood, New World Order or Old? The Invasion of Kuwait and the Rule of Law, 55 MOD. L. REv. 153 (1992); Ved P. Nanda, The Iraqi Invasion of Kuwait: The U.N. Response, 15 S. ILL. U. L.J. 431 (1991); Oscar Schachter, United Nations Law in the Gulf Conflict, 85 AM. J. INT'L L. 452 (1991); George K. Walker, The Crisis Over Kuwait, August 1990-February 1991, 1991 DUKE J. COMP. \& INT'L L. 25.

24. Cf. Diggs v. Shultz, 470 F.2d 461, $465-67$ (D.C. Cir.), cert. denied, 411 U.S. 931 (1972).

25. A non-self-executing treaty requires implementing legislation. Foster v. Neilson, 27 U.S. (2 Pet.) 253, 314 (1828). But see United States v. Percheman, 32 U.S. (7 Pet.) 51 (1833). Because both the Convention on the Service Abroad of Judicial and Extrajudicial Documents in Civil or Commercial Matters, opened for signature Nov. 15, 1965, art. 2, 20 U.S.T. 361, 362, 658 U.N.T.S. 163, 165-67 [hereinafter Hague Service Convention], and the Convention on the Taking of Evidence Abroad in Civil or Commercial Matters, opened for signature Mar. 18, 1970, art. 2, 23 U.S.T. 2555, 2558, 847 U.N.T.S. 231, 241 [hereinafter Hague Evidence Convention], require each state to designate a Central Authority, the Conventions are non-self-executing to that extent. However, once the Authority has been designated, the remainder of the Conventions are self-executing, subject to permitted reservations. Thus, some provisions of the same treaty may be self-executing, and some may be non-self-executing. RESTATEMENT (THIRD), supra note $10, \S 111 \mathrm{cmt}$. h. For an example of a largely non-self-executing treaty dealing with civil litigation, see Convention on the Recognition and Enforcement of Foreign Arbitral Awards, June 10, 1958, 21 U.S.T. 2517, 330 U.N.T.S. 3 [hereinafter Arbitration Convention], implemented by 9 U.S.C. $\$ \S 201-208$ (1988).

"International treaties are not presumed to create rights that are privately enforceable . . . Courts will only find a treaty to be self-excuting if the document, as a whole, evidences an intent to provide a private right of action." Goldstar (Panama) S.A. v. United States, 967 F.2d 967, 968 (4th Cir.), cert. denied, 113 S. Ct. 411 (1992) (citations omitted). Jordan Paust argues that all treaties should be selfexecuting except those that would seek to declare war on behalf of the United States. Jordan J. Paust, Self-Executing Treaties, 82 AM. J. INT'L L. 760, 782-83 (1988). According to the Restatement (Third), there is a strong presumption that a treaty is self-executing if "the Executive Branch has not requested implementing legislation and Congress has not enacted such legislation." RESTATEMENT (THIRD), supra note $10, \S 111$ r.n. 5 . Nevertheless, decisions such as United States v. Thompson, 928 F.2d 1060, 1066 (11th Cir. 1991), have followed the Goldstar precedent in a wide variety of cases, some involving agreements over a half century old.

26. Cf. Foster, 27 U.S. (2 Pet.) at 314-16. If the treaty does not confer private rights, individuals cannot claim under such an agreement, regardless of whether the treaty is self-executing or not. Argentine Republic v. Amerada Hess Shipping Corp., 488 U.S. 428, 442-43 (1989) (alternative holding); Dreyfus v. Von Finck, 534 F.2d 24, 29-30 (2d Cir. 1976), cert. denied, 429 U.S. 835 (1977). Moreover, even if a treaty confers rights on individuals, congressional implementing legislation (in the case of nonself-executing agreements) or a statute later in time than the treaty can limit those rights. See supra note 16 and accompanying text. The result may be that the United States is derelict in its obligations on the public law plane. See, e.g., Diggs, 470 F.2d at 465-67. There may be no way to enforce the obligation, however. RESTATEMENT (THIRD), supra note $10, \S 111$ r.n. 7. To the extent that legislation fails to implement the treaty, the United States may be in default of its international obligations, RESTATEMENT (THIRD), supra note 10, $111 \mathrm{cmt}$. h \& r.n. 5, but the litigants can only claim under what the legislature has enacted.

If private party litigants can persuade their government to espouse their claim of a denial of a treaty right, if the International Court of Justice accepts jurisdiction of the case, and if a judgment is rendered in favor of the claimant state, then U.N. CHARTER art. 94(2) allows the claimant state to bring the 
(for example, transfer of venue between federal courts) and is constitutionally invoked, the court has the relatively simple task of applying the statute according to its terms. If $\mathrm{State}^{27}$ or foreign ${ }^{28}$ law considerations are involved, the court applies them as policy factors if the statute permits. In international law terms, the United States is seen as one "state" on the international plane, despite being a federal republic. ${ }^{29}$ Nevertheless, federal courts must apply State procedural law whenever State substantive law applies, applying federal law would change the outcome of the case, and there is no directly relevant Federal Rule of Civil Procedure. ${ }^{30}$ If the case is governed by federal substantive principles, the federal court is much more free (in most cases, totally free) to apply federal procedure. Moreover, in transnational cases, there may be a strong inclination, perhaps almost a presumption, that the court will apply federal common law in the "procedural" sense too. ${ }^{31}$

In terms of State court jurisprudence, the Federal Rules of Civil Procedure do not apply of their own force, although more than half the States have copied some or all of them. ${ }^{32}$ The Supremacy Clause requires application of treaties of the United States and federal statutes by the State courts. ${ }^{33}$

\section{III}

\section{Favoritism and Balance In Federal Civil Litigation}

In some situations, the federal system, through rules of procedure, statutes, treaties, decisional law, and occasionally the Constitution itself, has displayed favoritism, by conferring benefits on classes of litigants. In other situations, the federal courts have followed common principles, sometimes stated in procedural rules or statutes or in their application, that are balanced as to all parties concerned. This section discusses policies behind each of these choices.

matter to the U.N. Security Council if the losing state does not comply with the judgment. The article 94 procedure has never been invoked. Mary Ellen O'Connell, The Prospects for Enforcing Monetary Judgments of the International Court of Justice: A Study of Nicaragua's Judgment Against the United States, 30 VA. J. INT'L L. 891, 905-12 (1990).

27. See 28 U.S.C. $\$ 1404$ (a) (1988), construed in the context of State law on choice of forum clauses in Stewart Org. v. Ricoh Corp., 487 U.S. 22, 27-32 (1988).

28. If it be assumed that the act abroad is not legitimate under that state's law, consider the balancing approach inherent in the analysis of FED. R. CIV. P. 37 sanctions in Societe Internationale Pour Participations Industrielles et Commerciales, S.A. v. Rogers, 357 U.S. 197, 208-12 (1958).

29. United States v. Belmont, 301 U.S. 324, 331 (1937).

30. Compare Burlington N.R.R. v. Woods, 480 U.S. 1, 4-6 (1987), and Hanna v. Plumer, 380 U.S. 460, 463-74 (1965), with Guaranty Trust Co. v. York, 326 U.S. 99, 107-12 (1945).

31. Compare West v. Conrail, 481 U.S. 35, 37-38, 40 (1987), with Walker v. Armco Steel Corp., 446 U.S. 740, 744-53 (1980). This is particularly true in international and maritime transactions. Texas Indus., Inc. v. Radcliff Mat'ls, Inc., 451 U.S. 630, 641 (1981); see also Verlinden B.V. v. Central Bank of Nig., 461 U.S. 480, $493-97$ (1983) (Foreign Sovereign Immunities Act).

32. Stephen N. Subrin, Federal Rules, Local Rules, and State Rules: Uniformity, Divergence, and Emerging Procedural Patterns, 137 U. PA. L. REV. 1999, 2029 n.154 (1989).

33. U.S. CONST. art. VI; see also Hines v. Davidowitz, 312 U.S. 52, 62, 66 (1941); Asakura v. Seattle, 265 U.S. 332, 341 (1924); Gibbons v. Ogden, 22 U.S. (9 Wheat.) 1, 210-11 (1824); Ware v. Hylton, 3 U.S. (3 Dall.) 199, 236-37 (1796); Burbank, supra note 4, at 1479-80. 


\section{A. Indicia of Favoritism}

Within U.S. domestic jurisprudence, certain parties are given special consideration: the United States, ${ }^{34}$ officers of the United States acting within the scope of their employment, ${ }^{35}$ the States, ${ }^{36}$ indigents, ${ }^{37}$ and mariners. ${ }^{38}$ Some of the parties in domestic litigation have their transnational counterparts. Indigency knows no national borders, and mariners from other nations frequently find their way to our shores.

Before enactment of the Foreign Sovereign Immunities Act of $1976,{ }^{39}$ the Department of State, speaking through the Department of Justice, often took capricious turns as to when a transaction was "commercial" for purposes of determining immunity. ${ }^{40}$ Even today, there are special service provisions under the Act. ${ }^{41}$ The act of state doctrine ${ }^{42}$ perhaps demonstrates the courts' reluctance to enter the hurly-burly arena of foreign relations. ${ }^{43}$

34. E.g., FED. R. CIv. P. 4(d)(4) (special service rules for suits against the United States); see also Suits in Admiralty Act, 46 U.S.C. APP. $\$ 742$ (1988), incorporated by reference in Public Vessels Act, id. $\$ 782$ (special rules in actions under the Acts).

35. E.g., FED. R. CIV. P. 4(d)(5) (special service rules for suits against federal officers, agencies); see also 32 C.F.R. §§ 97.1-97.6 (1993) (special procedures for testimony by U.S. Department of Defense personnel).

36. E.g., FED. R. CIV. P. 4(d)(6) (special service rules for service against the States, or State officers, in accordance with the rules of that State for service on such defendants); see also U.S. CONST. amend. XI.

37. 28 U.S.C. \& 1915 (indigents may be allowed to proceed in forma pauperis); see also FED. R. CIV. P. 4(c)(2)(B)(i) (marshal service available for indigents).

38. 28 U.S.C. \& 1916 (mariners allowed to proceed without prepayment of fees); see also FED. R. CIV. P. 4(c)(2)(B)(i) (entitlement to marshal service); Harden v. Gordon, 11 F. Cas. 480, 483 (C.C.D. Me. 1823) (No. 6047). Marshal service in maritime cases may be justified by the vagrancy of vessels and because of the need to assert the jurisdiction of the U.S. courts in sometimes rugged situations on the docks.

39. 28 U.S.C. $\S \S 1330,1391(f), 1441(d), 1602-1611$.

40. E.g., Rich v. Naviera Vacuba S.A., 295 F.2d 24, $25-26$ (4th Cir. 1961) (per curiam); Monroe Leigh, Sovereign Immunity -The Case of the "Imias," 68 AM. J. INT'L L. 280 (1974); see also H.R. REP. No. 1487, 94th Cong., 2d Sess. 8-12 (1976), reprinted in 1976 U.S.C.C.A.N. 6604, 6606-11; Michael Sandler et al., Sovereign Immunity Decisions of the Department of State: May 1952 to January 1977, 1977 DigEST App., at 1017. For analysis of the structure of the Soviet Union's state trading companies that might seek immunity during the Cold War era, see Neill H. Alford, Jr., MODERN ECONOMIC WARFARe (LAW AND tHE NAVAl PARTICIPANT) 86-88 (U.S. Naval War College International Law Studies v. 56,1967$)$.

41. 28 U.S.C. $\$ 1608$.

42. The doctrine has obvious political overtones, as noted in Banco Nacional de Cuba v. Sabbatino, 376 U.S. 398, 428 (1964). It was reduced in scope under the amendment of the same name, 22 U.S.C. $\$ 2370(\mathrm{e})(2)$, and subsequent cases, e.g., Alfred Dunhill of London, Inc. v. Republic of Cuba, 425 U.S. 682, 705 (1976) (commercial acts not covered); First Nat'l City Bank v. Banco Nacional de Cuba, 406 U.S. 759 (1972) (plurality opinion) (doctrine does not bar counterclaim); Kalamazoo Spice Extraction Co. v. Government of Socialist Eth., 729 F.2d 422 (6th Cir. 1984) (violation of treaty vitiates defense); Republic of Iraq v. First Nat'l City Bank, 353 F.2d 47 (2d Cir. 1965), cert. denied, 382 U.S. 1027 (1966) (property outside the jurisdiction). Its "genie" was recently put back into the bottle as a choice of law rule. W.S. Kirkpatrick \& Co. v. Environmental Tectonics Corp., 493 U.S. 400, 404-10 (1990); see also Peter D. Trooboff, International Decisions, 84 AM. J. INT'L L. 550, 552-53 (1990).

43. Before enactment of the Foreign Sovereign Immunities Act of 1976 , the courts, confronted with immunity claims where the Department of State had not filed a suggestion, tended to deny immunity unless it was "plain that the activity ... [fell] within [a] categor[y] of strictly political or public acts about which sovereigns have traditionally been quite sensitive." Victory Transp. Inc. v. Comisaria 
Treaties have also demonstrated favoritism by allowing nations to choose, for example, the preferred methods of service, ${ }^{44}$ to deny letters of request for pretrial discovery of documents, ${ }^{45}$ and to elect to enforce awards deemed commercial under the law of the ratifying state. ${ }^{46}$

However, there is a critical difference between the special privileges afforded by treaties and other forms of favoritism. International law recognizes the equality of all states, large and small, ${ }^{47}$ and all states have an equal opportunity to choose to become party to or to remain outside a treaty network, perhaps with reservations permitted by the agreement. The doctrine of equality is implicit in the balancing process described next.

\section{B. Indicia of Balancing}

In domestic jurisprudence, there are several examples of the balancing of competing interests: for example, the standard of notice in which the cost to the plaintiff is measured against the relative certainty of forms of service, ${ }^{48}$ the relative fairness of venue transfer for each of the litigants, ${ }^{49}$ and the options for discovery responses. ${ }^{50}$

At the transnational level, some of the same considerations also apply, but in a different context. For example, at least a summary of the complaint in the foreign defendant's language would probably be required for adequate notice under U.S. due process. ${ }^{51}$ In addition to the possibility of refusal of the receiving state to enforce a judgment based on a failure of service under U.S. due process standards, there is the further risk that such judgments will not be

General de Abastecimientos y Transportes, 336 F.2d 354, 360 (2d Cir. 1964), cert. denied, 381 U.S. 934 (1965). This approach, occurring during the Tate Letter era, at about the same time as Sabbatino and its progeny were being decided, permitted the courts to escape political involvement. If the transaction fell within the Victory list of categories, immunity was granted. If otherwise, and therefore "commercial," as defined in Victory, the transaction could be litigated.

44. Hague Service Convention, supra note 25 , arts. $8,10,20$ U.S.T. at 363,658 U.N.T.S. at $169-71$ (options for receiving state to declare opposition to diplomatic service; mail service; service by originating state's officers through state of destination's officers; service directly through state of destination's officers).

45. Hague Evidence Convention, supra note 25, art. 23, 23 U.S.T at 2568, 847 U.N.T.S. at 245.

46. Arbitration Convention, supra note 25 , art. 1(3), 21 U.S.T. at 2519,330 U.N.T.S. at 38 . See, e.g., George K. Walker, Trends in State Legislation Governing International Arbitrations, 17 N.C. J. INT'L L. \& COM. REG. 419, 450-53 (1992), and sources cited for analysis of the definition of "commercial" in international arbitrations.

47. U.N. Charter art. 2, para. 1.

48. Mullane v. Central Hanover Bank \& Trust Co., 339 U.S. 306, 313-20 (1950); see also Tulsa Profll Collection Serv., Inc. v. Pope, 485 U.S. 478 (1988).

49. 28 U.S.C. $\$ 1404(\mathrm{a})(1988)$.

50. E.g., FED. R. CIV. P. 33(c).

51. See, e.g., Lemme v. Wine of Japan Import, Inc., 631 F. Supp. 456, 464 (E.D.N.Y. 1986). The Hague Service Convention, supra note 25, art. 5, 20 U.S.T. at 362-63, 658 U.N.T.S. at 167, declares that Convention Central Authorities "may require the document to be written in, or translated into, the official language or one of the official languages of the state addressed." United States v. Mosquera, 816 F. Supp. 168, 177 (E.D.N.Y. 1993), required the government to supply a translated copy of the indictment and relevant statutory provisions cited in the indictment, grounding its rules in the due process clause. If such becomes the rule in criminal litigation, government-oriented cases such as antitrust suits filed by the United States may be the next candidates for such a requirement, at least as to the notice of suit, followed by private party litigation. 
enforced in the receiving state because of failure to comply with the receiving state's service rules. ${ }^{52}$ The same kind of analysis applies to forum non conveniens dismissal cases ${ }^{53}$ and to application of discovery sanctions. ${ }^{54}$

The balancing approach has been with us for quite a while. The Restatement (Second) of Foreign Relations Law (1965), drawing on cases of the 1950s and developing conflict of laws concepts, included the famous Section $40,{ }^{55}$ which has gained a considerable following in the courts. ${ }^{56}$ The Restatement (Third) of Foreign Relations Law (1987), which drew on later cases, the Restatement (Second) of Conflict of Laws (1971), and the thinking of commentators, including Professor Lowenfeld's Hague lectures, ${ }^{57}$ has continued the trend with a rule of reasonableness in a three-fold categorization of jurisdiction: jurisdiction to prescribe, to adjudicate, and to enforce. ${ }^{58}$

The Federal Rules of Civil Procedure are initially concerned with jurisdiction to adjudicate, that is, "to subject persons or things to the process of (the federal) courts ... in . . civil ... proceedings[.]"59 For example, in the event of noncompliance, the court may apply its enforcement jurisdiction, ${ }^{60}$ perhaps in the form of sanctions under Rule 4 or Rule 37 . However, jurisdiction to prescribe is also involved, since the federal courts system, through the Federal Rules, can "make its law applicable to the activities, relations, or status of persons . . by administrative rule, or by determination of a court."61

Both prescriptive and adjudicatory jurisdiction operate on a basic premise of reasonableness. ${ }^{62}$ The reasonableness principle is qualified by "cumulative

52. See, e.g., Letter from Alan J. Kreczko, U.S. Department of State Deputy Legal Adviser, to Administrative Office of U.S. Courts and National Center for State Courts (Mar. 14, 1990), reprinted in Notice of Other Recent Documents, 30 I.L.M. 260 (1991).

53. Piper Aircraft Co. v. Reyno, 454 U.S. 235, 255-61 (1981).

54. See supra note 28 and accompanying text.

55. RESTATEMENT (SECOND) OF FoREIGN RELATIONS LAW OF THE UNITED STATES $\$ 40 \& \mathrm{cmts}$. \& r.nn. 1-3 (1965), citing inter alia United States v. General Elec. Co., 115 F. Supp. 835, 878 (D.N.J. 1953); Restatement (SECOND) OF CONFLICT OF LAwS $\$ 94$ (Tent. Draft No. 4, 1957).

56. See, e.g., In re Grand Jury Proceedings Bank of N.S., 740 F.2d 817, 826-31 (11th Cir. 1984), cert. denied, 469 U.S. 1106 (1985); Timberlane Lumber Co. v. Bank of Am., 749 F.2d 1378, 1382-86 (9th Cir. 1984); Montreal Trading Ltd. v. Amax Inc., 661 F.2d 864, 869-70 (10th Cir. 1981), cert. denied, 455 U.S. 1001 (1982); Mannington Mills, Inc. v. Congoleum Corp., 595 F.2d 1287, 1302 (3d Cir. 1979); United States v. First Nat'l City Bank, 396 F.2d 897, 902-05 (2d Cir. 1968).

57. Andreas F. Lowenfeld, Public Law in the International Arena: Conflict of Laws, International Law, and Some Suggestions for Their Interaction, 163 RECUEIL DES COURS 311 (1979). Professor Lowenfeld was associate reporter for the RESTATEMENT (THIRD), supra note 10.

58. RESTATEMENT (THIRD), supra note $10, \S 401$. For an example of the citation of the cases, supra note 56, the RESTATEMENT (SECOND) OF CONFLICT OF LAWS (1971) (revised 1986), and the commentators, see RESTATEMENT (THIRD), supra note 10, § 403 r.nn. 1-10.

59. RESTATEMENT (THIRD), supra note $10, \S$ 401(b).

60. Id. § 401(c).

61. Id. \& 401(a).

62. Id. \$§ $403(1), 421(1)$. One might compare this with the more automatic approach in United States v. Aluminum Co. of Am., 148 F.2d 416, 443 (2d Cir. 1945), as to prescriptive jurisdiction. See also Burbank, supra note 4, at 1461-62. To be sure, prescriptive jurisdiction also requires at least some territorial nexus, RESTATEMENT (THIRD), supra note 10, $\S 402(1)-402(2)$, but since the initial filing of the suit, as well as its management, is within the territory of the United States or will have effect therein, there seems to be no difficulty with that hurdle. 
relevant factors" in the case of prescriptive jurisdiction ${ }^{63}$ and by discrete tests of minimal reasonableness for adjudicatory jurisdiction. ${ }^{64}$ On the other hand, enforcement jurisdiction is predicated upon initial prescriptive and adjudicatory jurisdiction, qualified by a requirement of reasonable relationship to the laws or regulations to which it is directed, a determination of violation, and the proportionality of the sanction to the gravity of the violation. Extraterritorial enforcement can be imposed if the party has reasonable notice of the matter and opportunity to be heard. ${ }^{65}$

The Restatement (Third) of Foreign Relations Law approach to prescriptive jurisdiction has not been universally accepted by the courts. ${ }^{66}$ Courts and commentators have argued that the judiciary lacks expertise and institutional capacity to assess questions of national interests and foreign relations problems. $^{67}$ Others have said there has been an inevitable bias toward U.S. interests in these cases. ${ }^{68}$ Others object to the amount of time busy courts must devote to resolving these issues. ${ }^{69}$

In support of the Restatement (Third) position, it should be noted that U.S. plaintiffs' complaints have been dismissed, or their discovery denied, in transnational cases. ${ }^{70}$ A majority of the lower federal courts seem to be able

63. RESTATEMENT (THIRD), supra note $10, \S 403$ (2), whose comment $b$ declares that the list is not exhaustive.

64. Id. $\S 421$ (2) \& cmt. c. Query, however, whether a stronger case for adjudication could be made where the linkage satisfies more than one test. Consider, for example, the case of a national domiciled in a state who registers a thing in that state and regularly carries on business in that state. To that extent, a court might proceed by analysis analogous to that for prescriptive jurisdiction under $i d$. $\S 403(2)$ to "build a stronger case" for the decision, whichever way it would go.

65. Id. § 431 .

66. E.g., Laker Airways Ltd. v. Sabena, Belgian World Airlines, 731 F.2d 909, 948-53 (D.C. Cir. 1984).

67. Id. at 949; James M. Grippando, Declining to Exercise Extraterritorial Antitrust Jurisdiction on Grounds of International Comity: An Illegitimate Extension of the Judicial Abstention Doctrine, 23 VA. J. INT'L L. 395, 400 n.22 (1983). Similar criticisms have been voiced in conflict of laws cases where interest analysis has been employed. See, e.g., Neumeier v. Kuehner, 286 N.E.2d 454 (N.Y. 1972), which criticized Babcock v. Jackson, 191 N.E.2d 279 (N.Y. 1963), for its failure to take into account all the underlying policies of statutes, noting discovery of additional policies through scholarly research, and which substituted a set of rules for guest-passenger cases.

68. Laker Airways, 731 F.2d at 951; Burbank, supra note 4, at 1463; Harold C. Maier, Interest Balancing and Extraterritorial Jurisdiction, 31 AM. J. COMP. L. 579 (1983). Occasional complaints of bias also have arisen in the conflicts field. See, e.g., DAVID F. CAVERS, THE CHOICE-OF-LAw PROCESS 20-23 (1965); Burbank, supra note 4, at 1463-64. The "better-law" approach might be susceptible to this criticism. See, e.g., Haines v. Mid-Century Ins. Co., 177 N.W.2d 328 (Wis. 1970). But see Robert A. Leflar, True "False Conflicts," Et Alia, 48 B.U. L. REV. 164, 168 (1968).

69. Consider what happened to the vested rights doctrine in the field of conflict of laws. See, e.g., Noe v. United States Fidelity \& Guar. Co., 406 S.W.2d 666 (Mo. 1966) (characterization as substance or procedure); Kilberg v. Northeast Airlines, 172 N.E.2d 526 (N.Y. 1961) (public policy); Haumschild v. Continental Cas. Co., 95 N.W.2d 814 (Wis. 1959) (characterization as to the nature of the action). As Barkonic v. General Admin. of Civ. Aviation of People's Republic of China, 923 F.2d 957 (2d Cir. 1991), held with respect to Kilberg, many jurisdictions (such as New York) that at one time adhered to characterization theories have abandoned them in favor of other principles, e.g., those of Neumeier v. Kuehner, 286 N.E.2d 454, 457-58 (N.Y. 1972), in New York, and its progeny, e.g., Cooney v. Osgood Mach., Inc., 612 N.E.2d 277 (N.Y. 1993).

70. Timberlane Lumber Co. v. Bank of Am., 749 F.2d 1378, 1380, 1386 (9th Cir. 1984), cert. denied, 472 U.S. 1032 (1985) (dismissal of complaint); In re Westinghouse Elec. Corp. Uranium Contracts Litig., 563 F.2d 992, 994, 998 (10th Cir. 1977) (discovery sanctions order reversed in favor of U.S. subsidiary 
to manage prescriptive jurisdiction. ${ }^{71}$ Moreover, prescriptive jurisdiction places the burden on parties and their counsel to develop and argue factors and facts. If a lawyer can develop a record for a complex antitrust case, then surely she can use some of these facts, and develop others, to help the court reach an informed prescriptive decision.

\section{IV}

\section{The Odyssey of Rules 4, 26, and 28: From Balance to Favoritism AND BACK TO BALANCE?}

As previously noted, ${ }^{72}$ the Federal Rules of Civil Procedure have been subject to numerous proposals for amendments, ranging from cosmetic changes to major shifts in policy. Although there have been other proposals affecting transnational practice, we will consider only the three rules whose 1993 amendment proposals raised major issues in transnational civil litigation: the proposed amendments of waiver of service provisions for Rule 4, foreigncountry discovery provisions for Rule 26 , and foreign-country deposition procedures for Rule $28 .^{73}$

\section{A. Rule 4 and Waiver of Service}

The 1989 amendments to the Federal Rules included Proposed Rule 4(d), which introduced the concept of waiver of service. ${ }^{74}$ Although the rule would not have required that plaintiffs use the waiver of service method, there was a strong cost incentive to employ the method. "Every other defendant ... [would have] a duty to avoid unnecessary costs of service of a summons by waiving service in accordance with the rule." of the commencement of the action and request that the defendant waive service of a summons." class mail or other equally reliable means," of imposition of costs for failure to comply with the request absent good cause for such failure. Costs for failure to comply with a request for waiver would have included the costs of conventional service in the United States (or by specified alternatives if service were effected in a foreign country) and "a reasonable attorney's fee, of any motion required to collect such costs."

of Canadian corporation where Canadian law forbade production of documents in Canada).

71. Burnham v. Superior Court, 495 U.S. 604 (1990), with its approval of tag jurisdiction for due process purposes-at least insofar as Justice Scalia was concerned-might be a signal that U.S. courts are diverging from the Restatement's internationalist perspective. Compare Burnham with RESTATEMENT (THIRD), supra note 10, § $102 \mathrm{cmt}$. e.

72. See supra note 4.

73. See also supra notes $6-8$ and accompanying text.

74. Except for service on the United States, U.S. corporations, incompetents, or infants. Preliminary Draft, supra note 4, 127 F.R.D. at 270-71

75. Id. at 271.

76. Id.

77. Id.

78. Id. at 273. 
Defendants waiving service would not waive objections to venue or personal jurisdiction. ${ }^{79}$ The new procedure was designed, according to the Advisory Committee Notes,

[ $t$ ]o eliminate the costs of service of a summons on many parties and to foster cooperation among adversaries and counsel. This device should be useful in dealing with furtive defendants or those who are outside the United States and can be actually served only at substantial expense. ${ }^{80}$

The Committee also thought that

[b]ecause the waiver would be consensual, the transmission of a request to a foreign country should give no offense even to foreign governments that have withheld their assent to service by mail ... . Because of the unreliability of some foreign mail services, the longer period of 60 days is provided for a return of a notice and request for waiver sent abroad. ${ }^{81}$

The alternate methods for service in foreign countries were retained in Rule 4 and updated to include the Service Convention where it applied. ${ }^{82}$ These options, however, would have played a subordinate role to the waiver of service provision, which would become the primary vehicle for serving to defendants abroad. Under the present rule, use of the choices set out in Rule 4(i) is a clear option, as long as federal or state law authorizes extraterritorial service. Although Rule 4(i)(1)(D) authorizes service "by any form of mail, requiring a signed receipt, to be addressed and dispatched by the clerk of the court to the party to be served," if that method is objectionable in the foreign country, the plaintiff can use other options listed in the rule for non-Convention states or get an order of court ${ }^{83}$ directing service under the Convention. The 1989 proposals would have removed this flexibility.

While the amendments were before the U.S. Supreme Court, the Embassy of Great Britain expressed two concerns. First, extraterritorial mailing of requests under proposed or Rule 4(d), coupled with the potential for cost shifting if the requests were declined, would contravene the letter or spirit of the Hague Service Convention. ${ }^{84}$ Second, at least by omission, the rule appeared to be inconsistent with the Foreign Sovereign Immunities $\mathrm{Act}^{85}$ with respect to

79. Id. at $270-71$. It was also noted, id. at 288 , that cost shifting should not occur if "defendant .. was insufficiently literate in English to understand" the documents served. There was a parallel amendment to FED. R. CIV. P. 12(a). Id. at 305-06.

80. Id. at 287.

81. Id. at 288 (citing Peter Heidenberg, Service of Process and the Gathering of Information Relative to a Law Suit Brought in West Germany, 9 INT'L LAW. 725, 728-29 (1975)). Heidenberg, supra, at 72829, would appear to have little or nothing to do with the statement in Preliminary Draft, supra note 4, 127 F.R.D. at 288 , that because the waiver under the proposed rule would be consensual, there would be no offense to foreign governments that had withheld assent to service by mail. Heidenberg, supra, at $728-29$, deals with service by publication from Germany.

82. Compare Preliminary Draft, supra note 4, 127 F.R.D. at 274-75, with FED. R. CIV. P. 4(i). Besides specifically mentioning and being keyed to the Hague Service Convention, supra note 25 , the draft rule would have also eliminated the requirement of explicit authorization under federal or State law for extraterritorial service. Preliminary Draft, supra note 4, 127 F.R.D. at 291-93. For analysis of FED. R. CIV. P. 4(i), see Burbank, supra note 4, at 1482-84.

83. FED. R. CIV. P. 4(i)(1)(E).

84. Hague Service Convention, supra note 25.

85. See supra notes $39-43$ and accompanying text. 
service on agencies and instrumentalities of foreign states. The U.S. Department of Justice, which had expressed no comment when the rule was originally proposed, took the position, essentially echoing State Department concerns, that to avoid possible offense to other governments, it would be preferable for the rule to restrict the request-for-waiver to defendants located within the United States. ${ }^{86}$ "[P]resumably[, this was] ... why the proposed amendment was returned by the Supreme Court for further study."

In May 1992, the Advisory Committee on Civil Rules submitted another version of Rule 4(d), which was substantially similar to the 1989 proposal $^{88}$ The Committee, after further study, concluded that the potential benefits to litigants-both plaintiffs and defendants-justified use of the request-for-waiver procedure in cases involving foreign defendants. The Committee amended the text of the Rule and the Committee notes, and the proposed new Forms 1A and $1 \mathrm{~B},{ }^{89}$ to try to ameliorate concerns expressed by the United Kingdom and the Justice Department. The Committee revision attempted to make clear that the request for waiver of service-"which, in fact, [would] afford ... significant potential benefits" to defendants residing in foreign countries through elimination of costs and time to respond-"is a private, nonjudicial act that does not purport to effect service or constitute any directive from a court." 90 The Committee also pointed out that the Committee Notes had addressed the criticism "that declination, pursuant to foreign law, to waive service when requested by mail could result in unfair cost-shifting" by explaining that "costshifting would be inappropriate if a refusal is based upon a policy of the foreign government prohibiting all waivers of service." 11

The Committee Notes offered the same justifications but added:

There is no useful purpose achieved by requiring a plaintiff to comply with all the formalities of service in a foreign country, including costs of translation, when suing a defendant manufacturer, fluent in English, whose products are widely distributed in the United States. ${ }^{92}$

The Notes point out that the new text clarifies some confusion among plaintiffs caused by the old text, which frequently had been interpreted as allowing defendants to effect service by mail unilaterally. "It is more accurate to describe the communication sent to the defendant as a request for a waiver of formal service." 93 The Notes then describe advantages to a foreign defendant:

86. Pointer letter, supra note 4, Attachment B, at 1, 146 F.R.D. at 521. For criticism of the 1989 proposals, see also Burbank, supra note 4, at 1484-90.

87. Pointer letter, supra note 4, Attachment B, at 1, 146 F.R.D. at 521.

88. Compare Pointer letter, supra note 4, Attachment A, at 5-7, with Preliminary Draft, supra note 4, 127 F.R.D. at $270-73$.

89. Proposed Form 1A, Notice of Lawsuit and Request for Waiver of Service of Summons, reprinted in Amendments, supra note 4, 146 F.R.D. at 718; Form 1B, Waiver of Service of Summons, reprinted in Amendments, supra note 4, 146 F.R.D. at 719.

90. Pointer letter, supra note 4, Attachment B, at 1, 146 F.R.D. at 521.

91. Id.

92. Amendments, supra note 4, at 27, 146 F.R.D. at 561.

93. $I d$. 
by waiving service, the defendant can reduce the costs that may ultimately be taxed against it if unsuccessful in the lawsuit, including the sometimes substantial expense of translation that may be wholly unnecessary for defendants fluent in English. Moreover, a foreign defendant that waives service is afforded substantially more time to defend against the action than if it had been formally. served: under Rule 12, a defendant ordinarily has only twenty days after service in which to file its answer or raise objections by motion, but by signing a waiver it is allowed 90 days after the date the request for waiver was mailed in which to submit its defenses. Because of the additional time needed for mailing and the unreliability of some foreign mail services, a period of 60 days (rather than the thirty days required for domestic transmissions) is provided for a return of a waiver sent to a foreign country. ${ }^{94}$

The Notes also expressed hope that

since transmission of the notice and waiver forms is a private nonjudicial act, does not purport to effect service, and is not accompanied by any summons or directive from a court, use of the new procedure will not offend foreign sovereignties, even those that have withheld their assent to formal service by mail or have objected to the service-bymail provisions of the former Rule..$^{95}$

The Notes do not seem to have considered the fact, however, that there would be little difference in appearances, insofar as foreign recipients and foreign governments would be concerned, between receiving an envelope with a waiver of service form attached to the complaint and other papers, and receiving a copy of the complaint by mail, as under Rules $4(c)(2)(C)(i i)$ or (4)(i)(D), or Rules $4(c)(2)(i)$ or $4(e)$ if the latter incorporate states' mail service principles as an option. Under federal practice since 1983, the Federal Rules have required the plaintiff to complete process; the clerk issues process, which is given to the plaintiff for service. ${ }^{96}$

\section{The Notes would further distinguish the two methods:}

Unless the addressee consents, receipt of the request under the revised rule does not give rise to any obligation to answer the lawsuit, does not provide a basis for default judgment, and does not suspend the statute of limitations in those states where the period continues to run until service."

94. Id. at 28,146 F.R.D. at 562 .

95. Id.

96. FED. R. CIV. P. 4(a). See generally 2 JAMES WM. MOORE ET AL., MOORE'S Federal PRACTICE II 4 .04, 4.08[4], 4.09 (2d ed. 1994); 4A ChARLEs Alan WRIGHT \& ARTHUR A. Miller, FEDERAL PRACTICE AND PROCEDURE $\$ \S 1084,1092.1-93$ (2d ed. 1987) (commenting on FED. R. CIV. P. 4(a), 4(c)(2)(c)(ii)). Since many states allow mail service on defendants, those methods can also be employed under FED. R. CIV. P. 4(c)(2)(c)(i) and 4(e). See, e.g., DAVID D. SIEGEL, New YORK Practice $\$ \S 60-62,76$ A (2d ed. 1991, 1992 Supp.); 2A JACK B. WeinsteIN ET AL., NEW YORK CIVIL PRACTICE $\$ \S 2102.01,2103.05$ (1991), which note that New. York does not require filing of service of the complaint before mail service; a "notice of default" is sufficient. FED. R. CIV. P. 4(a), 4(d) compel service of the complaint with the summons, and in actions filed in the federal courts in New York, that procedure must be followed even if out-of-state service is sought under FED. R. CIV. P. 4(e). Other states allow mail service, perhaps by registered mail with return receipt requested, but a copy of the complaint must accompany the summons. See, e.g., N.C. R. CIV. P. 4(j)(1)(c), 4(j)(3), 4(j)(4)(a), $4(j)(4)(c), 4(j)(5), 4(j)(6)(c), 4(j)(7)(a), 4(j)(8)(c)$. In these jurisdictions that follow federal rule practice, plaintiff must comply with the registered or certified mail requirements if service is attempted under FED. R. CIV. P. 4(c)(2)(c)(i) or 4(e). The requirement of attaching the complaint to the summons copies the requirements of FED. R. CIV. P. 4(a), 4(d), which control.

97. Amendments, supra note 4, at 28, 146 F.R.D. at 562. 
The only adverse consequence to the foreign defendant is one shared by domestic defendants: the potential imposition of costs of service that a successful defendant would not otherwise have to bear. The Notes add that shifting expense would not be proper under the Rule if a foreign defendant's refusal to waive service was based on a policy of its government prohibiting all waivers of service. ${ }^{98}$ This latter confession and avoidance does not seem to consider the problem of a defendant who is not a national of the government in whose territory the waiver of service is effected by mail, for example, a U.S. or other national residing in such a country. The Hague Service Convention makes no distinction among defendants present in a state, which has the option to reject mail service under the Convention. ${ }^{99}$ Nor does it take into account the principle that many civil law states that are not Convention parties generally regard service of process-however it might be styled by the Federal Rules of Civil Procedure-as a sovereign act to be performed in their territory only by state officials and in accordance with that state's law. ${ }^{100}$

The Committee Notes also say that there would be little need to use the waiver of service option in countries like the United Kingdom, which accepts documents in English, and whose Central Authority under the Hague Service Convention acts promptly, and whose policies discourage residents from waiving formal service. ${ }^{101}$ This, of course, does not take into account the ingenuity (or ignorance) of U.S. lawyers who may decide to use the waiver of service option out of habit or for reasons of economy. Nor does it account for the requirement of many states perhaps exercising their option under the Convention ${ }^{102}$ of requiring translation of court documents in another language. As of early 1993, three nations had exercised that option. ${ }^{103}$ The Notes conclude by arguing that the waiver of service procedure offers "significant potential benefits" to a plaintiff when suing a defendant who is fluent in English but who is located in a country where documents must be translated into another language or where formal service will otherwise be costly or time-consuming. ${ }^{104}$ This declaration, of course, squarely overlooks the provisions of the

98. Id.

99. Hague Service Convention, supra note 25 , art. 10(a), 20 U.S.T. at 363, 658 U.N.T.S. at 169-71. See also supra note 44 and accompanying text. No declarations under the Convention, including that of the United States, differentiate between service on nationals of the receiving state and other defendants. See generally Reservations and Declarations to the Service Convention, supra note 25, Doc. 8-15, in 6A BENEDICT ON ADMIRALTY 8-150 (Frank L. Wiswall, Jr. ed., 6th ed. 1993).

100. RESTATEMENT (THIRD), supra note $10, \S 471$, cmt. b; Harry Leroy Jones, International Judicial Assistance: Procedural Chaos and a Program for Reform, 62 YALE L.J. 515, 537 (1953).

101. Amendments, supra note 4, at 29, 146 F.R.D. at 563.

102. Hague Service Convention, supra note 25, arts. 7,20 (b), 20 U.S.T. at 363, 365, 658 U.N.T.S. at $169,175$.

103. Reservations and Declarations, supra note 99, at 8-150.4, 8-150.9 to 8-150.15 (Federal Republic of Germany, Sweden, United Kingdom, and certain U.K. dependencies).

104. Compare Pointer Letter, supra note 4, Attachment A, at 18-19 (citing, inter alia, Bankston v. Toyota Motor Corp., 889 F.2d 172 (8th Cir. 1989)), and Gulley v. Mayo Found., 886 F.2d 161 (8th Cir. 1989)), with Preliminary Draft, supra note 4, 127 F.R.D. at 287. 
Service Convention, at least with respect to those states that have opted out of mail service or who require translation into a language other than English. ${ }^{105}$

One Committee member would have excluded foreign defendants from the request-for-waiver procedure: Despite the majority recommendation, the Committee included this Special Note:

If the Committee's proposal to make the request-for-waiver procedure available with respect to defendants located outside the United States is disapproved, Rule 4 need not be rejected in its entirety. Rather, one of two approaches could be adopted: (1) eliminate the cost-shifting feature that is the principal objection raised by the British Embassy (by adding a clause in the last sentence of Rule 4(d)(2) that excludes foreign defendants from the cost-shifting sanction), or (2) limit the Rule 4(d) procedure to domestic defendants (by eliminating the reference to subdivision (f) in the first sentence of Rule $4(\mathrm{~d})){ }^{106}$

After review by the Standing Committee, the Judicial Conference of the United States has chosen to exclude foreign-party litigation (cases where a plaintiff or a defendant are outside the United States) from the costs provisions of the waiver-of-service procedure of Proposed Rule 4(d). ${ }^{107}$

In litigation involving foreign defendants, an alternative service vehicle will be Proposed Rule 4(f), an update of present Rule 4(i):

Service Upon Individuals in a Foreign Country. Unless otherwise provided by federal law, service upon an individual from whom a waiver has not been obtained and filed, other than an infant or an incompetent person, may be effected in a place not within any judicial district of the United States:

(1) by any internationally agreed means reasonably calculated to give notice, such as those means authorized by the Hague Convention on the Service Abroad of Judicial and Extrajudicial Documents; or

(2) if there is no internationally agreed means of service or the applicable international agreement allows other means of service, provided that service is reasonably calculated to give notice:

(A) in the manner prescribed by the law of the foreign country for service in that country in an action in any of its courts of general jurisdiction; or

(B) as directed by the foreign authority in response to a letter rogatory or letter of request; or

(C) unless prohibited by the law of the foreign country, by

(i) delivery to the individual personally of a copy of the summons and the complaint; or

(ii) any form of mail requiring a signed receipt, to be addressed and dispatched by the clerk of the court to the party to be served; or

(3) by other means not prohibited by international agreement as may be directed by the court. ${ }^{108}$

105. See supra notes 99-100, 103-04 and accompanying text.

106. Pointer letter, supra note 4, Attachment B, at 1-2, 146 F.R.D. at 521-22. The Advisory Committee version also included a parallel amendment to FED. R. CIV. P. 12(a) for the request for waiver procedure. Compare Pointer letter, supra note 4, Attachment A, at 41-42, with Preliminary Draft, supra note 4, 127 F.R.D. at 305-07.

107. Amendments, supra note 4, at 6-9, 26-32, 146 F.R.D. at 540-43, 560-66.

108. Compare id. at 10-12, 146 F.R.D. at 544-46, with FED. R. CIV. P. 4(i). 
Besides explicit reference to the Service Convention and the former options preserved in Proposed Rule 4(f)(2), the ambit of the court's discretion in Proposed Rule 4(f)(3) has been qualified to track other international agreements. ${ }^{109}$

Thus, Proposed Rule 4(f) would seem to send a conflicting message. First, there is no direct indication of the primacy of the Service Convention as the preferred method by many states. Second, plaintiffs who compare Proposed Rule 4(d) with Proposed Rule 4(f) do not receive any assistance from the text of the Rule as to the place of waiver of service. Those who read the Notes may derive some comfort from them, but these are possibly misleading. The result is the very real risk, articulated by the United Kingdom during the drafting process, that plaintiffs, and therefore the U.S. courts, may inadvertently initiate an offense to the sovereignty of a state, either by violating the Service Convention as applicable to that state, or by offending that state's policies as to mail service in the absence of the Convention. ${ }^{110}$

\section{B. Rule 26 and Foreign-Country Discovery}

The 1989 proposals would have added this provision to Rule 26(a)(5), Discovery Methods:

If an applicable treaty or convention provides for discovery in another country, the discovery methods agreed to in such treaty or convention shall be employed; but if discovery conducted by such methods is inadequate or inequitable and additional discovery is not prohibited by the treaty or convention, a party may employ the methods here provided in addition to those provided by such convention or treaty. ${ }^{11}$

The amendment purported to reflect the policy of accommodation to internationally agreed methods of discovery expressed in the Aérospatiale concurring opinion, according to the Advisory Committee Notes of the 1989 version of the proposed rules. ${ }^{112}$ These Notes would have warned:

Attorneys and judges should be cognizant of the adverse consequence for international relations of unduly intrusive discovery methods that offend the sensibilities of those governing other countries .... If certain methods of discovery have been approved for international use, positive international relations require that these methods be preferred, and that other methods should not be employed if the approved methods are adequate to meet the need of the litigant for timely access to the information. ${ }^{113}$

The Notes also indicated however, that the amended Rule should provide a level playing field for U.S. parties and those located abroad:

On the other hand, the language added to the rule also requires that discovery proceed in a manner that is not "inequitable." International litigants should not be placed in a favored position as compared to American litigants similarly situated, especially in

109. Amendments, supra note 4, at $12,35,146$ F.R.D. at 546, 569.

110. See supra notes $89-92$ and accompanying text.

111. Preliminary Draft, supra note 4,127 F.R.D. at 318.

112. Id. at 320 (citing Société Nationale Industrielle Aérospatiale v. United States Dist. Ct. for the So. Dist. of Iowa, 482 U.S. 522, 547 (1987) (Blackmun, J., concurring)).

113. Preliminary Draft, supra note 4, 127 F.R.D. at 320 (citing inter alia Joseph J. Weis, Jr., The Federal Rules and the Hague Conventions: Concerns of Conformity and Comity, 50 U. PITT. L. REV. 903 (1989)). 
commercial matters with respect to which the similar American litigants may be their economic competitors. ${ }^{114}$

International litigants using the discovery rules should not be permitted to employ the Evidence Convention ${ }^{115}$ or similar international agreements to "create obstacles to discovery by an adversary. In general, full discovery should be available equally against all." However, where limits on discovery are imposed by "public authority," that is, foreign governments, but not at the request of the international litigant, "accommodation may be necessary to reconcile the requirement of [Rule 26] that discovery be equitable to the obligations imposed by the treaty."116 Thus, in a roundabout way, the Notes would urge treaty compliance, but only after making the broad-based statement for equality of treatment.

As in the case of the Rule 4(d) proposals, there were foreign government concerns over Rule 26. The principal issue was with respect to the Committee Notes, that provisions relating to discovery in foreign countries would be inconsistent with the Evidence Convention. The U.S. Justice Department believed that the change unnecessarily restricted discovery from foreign litigants and urged that the Rule not contain any language relating to foreign discovery. The result was that the Committee made minor changes in the text of the Rule and "more significant" amendments in the Notes that, at least in the Committee's view, represented "an appropriate balance between the competing considerations that affect foreign discovery." And as in the case of Rule 4, the Court returned the amendment for further consideration to the Judicial Conference. $^{117}$

Thus, the text of the Rule remained about the same ${ }^{118}$ in the Advisory Committee draft, but the Committee Notes included "significant changes" that reflect an "appropriate balance between the competing considerations that affect foreign discovery." 119

The new provision would apply only to discovery sought to be conducted within a country that is a treaty partner with the United States. It would not cover discovery requests "that a party subject to the power of the court provide in the United States," for example, answering interrogatories, appearing at a deposition, or producing documents in this country, from information that may be located abroad or derived from materials located abroad. The Notes caution that "nevertheless, in such situations, although not governed by the amendment to rule 26(a)(5), the court should consider, as part of its obligation to prevent discovery abuses involving foreign litigants, the availability and practicality of

114. Preliminary Draft, supra note 4, 127 F.R.D. at 320.

115. Hague Evidence Convention, supra note 25.

116. Preliminary Drafi, supra note 4,127 F.R.D. at 320-21.

117. Pointer letter, supra note 4, Attachment B, at 8, 146 F.R.D. at 528; see also Burbank, supra note 4 , at $1995-96$.

118. Compare Pointer letter, supra note 4, Attachment A, at 54, with Preliminary Drafi, supra note 4, 127 F.R.D. at 318.

119. Pointer letter, supra note 4, Attachment B, at 8, 146 F.R.D. at 529. 
discovery through convention methods." 120 Courts should also consider comity in deciding what discovery to permit in countries that are not treaty partners with the United States. On the other hand, Rule 26 would not require resort to Evidence Convention methods where such would be "inadequate." For example, a court might excuse a party from resorting to Convention methods "if a country in which necessary information is located has imposed a blanket reservation that would prevent such discovery." The Notes repeat the theme that domestic parties should not be disadvantaged at the expense of non-U.S. litigants, who could take advantage of broad U.S. discovery rules while asserting protections under a treaty or their own national laws. ${ }^{121}$ The Notes then seem to authorize discovery that would break the laws of a foreign country under certain circumstances:

Indeed, the court is not precluded by the rule from authorizing use of discovery
methods that may violate the laws of another country if necessary to assure that
discovery is not inadequate or inequitable and if not prohibited by a treaty or
convention with the United States. The court should however, exercise caution in
ordering such discovery, particularly if the impediment to the discovery is imposed at
the instance of the foreign authority, not at the request of the litigant or non-party
from whom information is sought. Moreover, in deciding upon an appropriate sanction
for failure to comply with an order for such discovery, the court should take into
account the fact that non-compliance was motivated by the party's need to conform
to the law of a foreign country. ${ }^{122}$

In no case, however, could a court authorize discovery by means that are prohibited by a treaty between the United States and the targeted foreign country, "for the proscriptions of the treaty take precedence over these rules." 123 The result of this could be said to be a supersession of the balancing process enunciated by the Court in Societe Internationale, ${ }^{124}$ if taken literally. The comity factor would seem to disappear. On the other hand, the Evidence Convention and international agreements like it would be given absolute priority if the United States is a party, and if any discovery procedures are forbidden in the agreement.

The net result would perpetuate the Aérospatiale holding. If the Convention states a method of discovery, and if a court would hold that the Convention

120. Pointer letter, supra note 4, Attachment A, at 70-71, reprinted in GARY B. BORN \& DAVID WESTIN, INTERNATIONAL CIVIL LITIGATION IN UNITED STATES COURTS 895-96 (2d ed. 1992) (citing by analogy Société Nationale Industrielle Aérospatiale v. United States Dist. Ct. for the So. Dist. of Iowa, 482 U.S. 522, 547 (1987)). Compare with Preliminary Draft, supra note 94 and accompanying text.

121. Pointer letter, supra note 4, Attachment A, at 71, reprinted in BORN \& WESTIN, supra note 120, at 895-96. Professor Oxman would vigorously dissent from this position: "[C]ourts must be particularly diligent in respecting the restraints of international law and treaties, since their decisions are not normally subject to review by an international tribunal. Indeed, the absence of outside judicial control necessitates a policy of self-restraint." Bernard H. Oxman, The Choice Between Direct Discovery and Other Means of Obtaining Evidence Abroad: The Impact of the Hague Evidence Convention, $37 \mathrm{U}$. MIAMI L. REV. 733, 748 (1983) (citations omitted); accord, Weis, supra note 113, at 927, 931.

122. Pointer letter, supra note 4, Attachment A, at 71, reprinted in BORN \& WESTIN, supra note 120 , at 896 (citing Societe Internationale Pour Participations Industrielles et Commerciales, S.A. v. Rogers, 357 U.S. 197, 208-12 (1958)).

123. Pointer letter, supra note 4, Attachment A, at 71, reprinted in BORN \& WESTIN, supra note 120 , at 896. Contra Laker Airways Ltd. v. Pan Am. World Airways, 103 F.R.D. 42,50 \& n.19 (D.D.C. 1984).

124. 357 U.S. at 208-12. 
method would be "inadequate" because of foreign state prohibition, then resort to the Convention method would not be required. ${ }^{125}$ This from Justice Blackmun's concurring and dissenting opinion is worth repeating:

Experience to date indicates that there is a large risk that the case-by-case comity 1 analysis now to be permitted by the Court will be performed inadequately and that the somewhat unfamiliar procedures of the Convention will be invoked infrequently. I fear the Court's decision means that courts will resort unnecessarily to issuing discovery orders under the Federal Rules of Civil Procedure in a raw exercise of their jurisdictional power to the detriment of the United States'[s] national and international interests. The Court's view of this country's international obligations is particularly unfortunate in a world in which regular commercial and legal channels loom ever more crucial. ${ }^{126}$

The result has been that most courts have refused to require first use of the Convention. ${ }^{127}$ By contrast, other states party to the Evidence Convention "have uniformly criticized the ... Aérospatiale holding and have viewed it as a failure by U.S. courts to honor treaty obligations assumed by the United States ."128 Proposed Rule 26(a)(5), by underscoring the optional nature of the Convention methods, "may have the opposite effect" of overemphasizing rule methodology at the expense of the Convention. ${ }^{129}$ Proposed Rule 26(a)(5)'s requirement of use of the Convention if it prohibits a discovery method ${ }^{130}$ seems logically inconsistent with the principle of optional use if a foreign state might block a Convention-based discovery request that violates the Convention. It would seem that the federal courts would inject themselves into the very kind of problem that they eschewed in the act of state cases, and in which they were involved through suggestions of immunity after the 1952 Tate letter. In each, Congress attempted to solve the problem. ${ }^{131}$

As with the Rule 4(d) proposals, the Advisory Committee noted that if the Rule 26(a) amendment were disapproved, the rest of the Rule 26 amendments (for example, those requiring early disclosure of discoverable information) that have generated a firestorm of protests, could go forward. ${ }^{132}$ The Standing Committee has decided not to submit the proposal to the Court. ${ }^{133}$

125. Compare supra notes 120-21 and accompanying text with Aérospatiale, 482 U.S. at 529-47. The concurring opinion would seem to agree on this point, i.e., that use of the Convention should not be required if resort to it would be "futile ... . But even then, an attempt to use the Convention will often be the best way to discover if it will be successful . . ." Id. at 567 (Blackmun, J., concurring).

126. Id. at 547-48 (Blackmun, J., concurring).

127. 1 BRUNO A. Ristau, INTERNATIONAL JUdiCIAL ASSISTANCE: CIVIL AND COMMERCIAL $\$$ 5-27, at 231 (1990 rev.); Gary B. Born \& Scott Hoing, Comity and the Lower Courts: Post-Aérospatiale Applications of the Hague Evidence Convention, 24 INT'L LAW. 393, 402 (1990).

128. RISTAU, supra note $127, \S 5-2-7$, at 231 . The difference between the U.S. courts' position on the Convention, and that of its Convention partners, could be seen as either a difference of opinion as to interpretation of the treaty or as an example of dualist jurisprudence. See supra text accompanying note 20 . Congress could cure the problem by legislation to bring the courts in line with other states' views, and such would trump Aérospatiale (and the Convention) under the later-in-time principle. See supra note 16 and accompanying text.

129. Monroe Leigh, Judicial Decisions, 81 AM. J. INT'L L. 944, 947 (1987).

130. See supra note 123 and accompanying text.

131. See supra notes $39-43$ and accompanying text.

132. Pointer letter, supra note 4, Attachment B, at 8, 146 F.R.D. at 528.

133. See Amendments, supra note 4 , at $78,104,146$ F.R.D. at $612,638$. 


\section{Rule 28 and Foreign-Country Depositions}

The 1989 proposals would have qualified Rule 28(b)'s provisions by incorporating Rule 26(a)(5)'s directions to use treaty-based discovery methods unless they would be "inadequate or inequitable." 134 Other Rule 28(b) amendments purported to conform it to the Evidence Convention ${ }^{135}$ or similar international agreements. ${ }^{136}$

As with Rule 4(d), the Supreme Court returned the proposals. ${ }^{137}$ The Advisory Committee's 1992 version was identical with the 1989 proposals. ${ }^{138}$ It was labeled "[n]on-controversial," perhaps surprisingly in view of the cautionary approach to the Rule 26(a)(5) amendments, ${ }^{139}$ which were incorporated by reference into Proposed Rule $28(b) .{ }^{140}$

\section{Summary: Back to Balancing}

As submitted to the Supreme Court, the costs provision for waiver of service in Rule 4(d) will not apply to litigation with a foreign party. Transnational litigants will also be able to use the alternative service methods in proposed Rule 4(f), an improvement on Rule 4(i). ${ }^{141}$ Foreign-country discovery provisions in Rule 26(a) have disappeared, as has the Rule 28(b) provision for depositions in foreign nations.

Thus, the state of the law has returned to where it was before the 1989 proposals went to the Supreme Court, except for the waiver of service provision in Rule 4. As a result, "a lot of carrying on in high places" began. ${ }^{142}$ What might, or should, be the course for the future?

\section{$\mathrm{V}$}

\section{PROJECTIONS FOR THE FUTURE; CONCLUSIONS}

Under the revised Federal Rules of Civil Procedure that took effect on December 1, 1993, Rules 4, 26, and 28, as they relate to foreign nations' service

134. Preliminary Draft, supra note 4, 127 F.R.D. at 321; see also id. at 318.

135. Hague Evidence Convention, supra note 25.

136. Preliminary Draft, supra note 4, 127 F.R.D. at 321-23.

137. Pointer letter, supra note 4, Attachment B, at 9,146 F.R.D. at 529.

138. Compare id., Attachment A, at 77.78, with Preliminary Draft, supra note 4, 127 F.R.D. at 32123.

139. See supra notes $118-23$ and accompanying text.

140. See Pointer letter, supra note 4, Attachment A, at 77.

141. Since that rule is permissive-that is, it says "service ... may be effected," see Amendments, supra note 4, at 11, 146 F.R.D. at 545-plaintiffs could employ other methods, such as service on individuals under state law when no federal statute requires otherwise, an option carried over from Rule 4(i). Compare Proposed Rule 4(e)(1), id. at 10,146 F.R.D. at 544, with FED. R. CIV. P. (c)(2)(c)(i). Use of alternative methods might be unwise if the methods are forbidden under the Convention or the other state's declaration.

142. A colleague has likened treaty negotiation and ratification to the mating of elephants: "A lot of carrying on in high places, and no one knows the result for at least 22 months." Perhaps the same could be said for amending the Federal Rules of Civil Procedure, at least where international litigation issues are involved. 
of process and discovery, operate as they did before 1989. The only exceptions are the new waiver of service provision in Rule 4 and updates to reflect Convention practice. The first obligation for the courts is treaty compliance. ${ }^{143}$ . The Rules Enabling Act speaks of superseding "laws" in favor of the Civil Rules; ${ }^{144}$ it says nothing about superseding treaties. Unless the courts are willing to apply a strict later-in-time rule in the face of a contrary, but earlier, treaty norm, the treaty rules should govern, ${ }^{145}$ particularly in view of the Supreme Court's cautious approach in applying the Civil Rules in domestic diversity cases $^{146}$ and its cautionary analysis in later-in-time situations involving prior treaties and later legislation. ${ }^{147}$ The federal courts should apply the balancing analysis only when a treaty does not govern a situation or when a treaty permits domestic court interpretation. Therefore, if the amendments to the Civil Rules, or the application or interpretation of them, are contradictory to U.S. treaty obligations, the treaty should govern. Treaty law is supreme on the public law plane ${ }^{148}$ and as a matter of domestic jurisprudence. ${ }^{149}$

If it is appropriate to manage international service of process or discovery by a balancing test, whether or not the Service or Evidence Conventions apply to the litigation, either for non-Convention litigation or within the Conventions' framework, should the test be articulated in federal legislation or in the Rules of Civil Procedure? Legislation binding on the federal and state courts ${ }^{150}$ has the advantage of national uniformity, and would tend to eliminate cases like

143. The Rules of Decision Act, 28 U.S.C. $\S 1652$ (1988), obligates the federal courts to enforce treaties, inter alia, "when they apply." See The Paquete Habana, 175 U.S. 677, 700 (1900); Burbank, supra note 4, at 1479; see also supra notes $10-26$ and accompanying text.

144. 28 U.S.C $\$ 2072$ (b) (1988). The word "laws" has been defined in the legislative history to mean statutes. H.R. REP. No. 100-889, 100TH CONG., 2D SESS. 27-28, reprinted in 1988 U.S.C.C.A.N. 5982, 5987-88 (citing Stephen B. Burbank, The Rules Enabling Act of 1934, 130 U. PA. L. REV. 1015, 1050-54 (1982)). Professor Burbank's research of the legislative history of the 1934 Act, predecessor to the present legislation, indicates that Congress was thinking of superseding only federal statutes. What negative inferences might be drawn, or whether the Congress even considered the problem, are left to conjecture. However, it is fairly clear that "laws" in the Act, then and now, equates to federal legislation.

145. For the most part, the Hague Service and Evidence Conventions, supra note 25, are selfexecuting. See supra notes $25-26$ and accompanying text. The rules drafters reached this conclusion, at least as to discovery prohibited by treaty, but they equivocated where a treaty would permit a discovery method and a foreign state would appear to deny it under the domestic laws. See supra notes 118-31 and accompanying text.

146. See Hanna v. Plumer, 380 U.S. 460 (1965), and the further elucidation in Stewart Org. v. Ricoh Corp., 487 U.S. 22 (1988), on the difference between Rules-oriented cases and statute-governed litigation. If such be the situation, at least the same analysis should apply to treaties as for legislation.

147. See supra note 16 and accompanying text.

148. As undoubtedly the U.K. Embassy was aware in making its objections. See supra notes 84-87 and accompanying text.

149. See supra notes $143-47$ and accompanying text.

150. U.S. CONST. art. VI. The Full Faith and Credit Act, 28 U.S.C. $\$ 1738$ (1988), is a venerable example of such. The Foreign Sovereign Immunities Act, supra note 39, is another. Other federal legislation affecting civil litigation, such as the Federal Arbitration Act, 9 U.S.C $\S \$ 1-16$, has not affected all issues in state courts. See Volt Inform. Sciences, Inc. v. Stanford Univ., 489 U.S. 468 (1989). Occasionally legislation has tacked on a reciprocity requirement for foreign litigants. See, e.g., Public Vessels Act, 46 U.S.C. $\$ 785$, construed in United States v. United Continental Tuna Corp., 425 U.S. 164 (1976). 
Schlunk ${ }^{151}$ by imposing a uniform national standard. On the other hand, Congress may have concerns more pressing than court procedure. If there is a need for amendment in the future, needed repairs to legislation may languish for years. ${ }^{152}$ The rules amendment process is quicker (approximately two years) and allows for greater involvement on the part of scholars and practitioners who have expertise in civil procedure (even though their work is still subject to congressional oversight). ${ }^{153}$ The federal courts are perceived abroad as the national courts of the United States, ${ }^{154}$ and most international litigation winds up there on account of the alienage or admiralty jurisdiction, or federal question coupled with the right of removal. Moreover, legislation, if applicable for both federal and state courts, has an all-or-nothing flavor to it; the Federal Rules can be used as an appropriate laboratory for change.

Any rules amendments, or any legislation, should be evenhanded in their application to domestic and foreign parties, unless there are special considerations, such as indigency or mariner status. ${ }^{155}$ Evenhandedness has been the policy underlying national-treatment clauses in bilateral agreements, as well as the policy of comity, both of which allow foreign nationals access to the courts

151. Volkswagenwerk Aktiengesellschaft v. Schlunk, 486 U.S. 694, 698-708 (1988) (upholding the Illinois courts' approval of in-State service on Volkswagen of America, Inc.; a wholly-owned subsidiary of Volkswagenwerk). Criticized, Burbank, supra note 4, at 1478-80. The dichotomy of analysis in the wake of Schlunk is illustrated by cases like Melia v. Les Grands Chais de France, 135 F.R.D. 28 (D.R.I. 1991), which initially inquired whether Rhode Island had an in-State service method so that service would be complete on defendant Les Grands Chais. Finding that the State long-arm statute's provision for in-State service of process on the Rhode Island Secretary of State completed service, Melia held Schlunk applicable, ruling that FED. R. CIV. P. 4(d)(3) applied to validate service on Les Grands Chais. On the other hand, there was no in-State long-arm service available for individuals such as defendant Helfrich, a resident of France, and thus resort to the Hague Service Convention, supra note 25, was necessary. Since France had not objected to mail service under article 10(a) of the Convention, notifying Helfrich by certified mail, return receipt requested, was proper. The significance of Schlunk, and now Melia, is that in jurisdictions whose long-arms apply across the board to all kinds of defendants, the Convention can be vitiated by service on a statutory officer who invariably is a domiciliary of the State in which service is made. In those jurisdictions, where the long-arm does not encompass all types of defendants, it is a reasonable prediction that the State legislature will soon begin the process of enacting amendments. Schlunk involved an agent-a local subsidiary-created by defendant, whereas service on statutory agents such as the Secretary of State in Melia proceeds on an implied consent theory of appointment.

152. Thirty years passed before Congress raised the diversity jurisdictional amount from $\$ 10,000$ to $\$ 50,000$. Compare 28 U.S.C. $\$ 1332$ (a) with Act of July 25, 1958, Pub. L. No. 85-554, § 2, 72 Stat. 415.

153. See supra note 4 and accompanying text for an example of recent congressional interest in the courts' rulemaking.

154. This has been true since the framing of the Constitution. Cf. ThE FEDERALIST No. 80, at 534, 535-38 (Alexander Hamilton) (Jacob E. Cooke ed., 1961). Today the federal courts have exclusive jurisdiction over admiralty and maritime cases. 28 U.S.C. $\& 1333(1)$. They may hear most maritime cases, either under the original jurisdiction or by removal. Id. $\S \S 1332(\mathrm{a})(2)-1332(\mathrm{a})(3), 1441(\mathrm{a})$. But see Verlinden B.V. v. Central Bank of Nig., 461 U.S. 480, $491-92$ (1983) (dictum, alienage jurisdiction does not extend to suits between aliens). They may hear claims arising under federal law; these often involve transnational issues. E.g., Verlinden (Foreign Sovereign Immunities Act of 1976, 28 U.S.C. $\S \S 1330,1391(f), 1441(d), 1602-1611$ ); Filartiga v. Pena-Irala, 630 F.2d 876 (2d Cir. 1980) (Alien Tort Statute, 28 U.S.C. $\$ 1350$ ). Removal from State courts is freely available. 9 U.S.C. $\$ 205$ (removal of actions involving arbitration under the Arbitration Convention, supra note 25); 28 U.S.C. \$\$ 1441(b)1441(d) (removal of claims arising under federal law, Foreign Sovereign Immunities Act cases); 28 U.S.C. $\$ 1367$ (supplemental jurisdiction).

155. See supra notes $37-38$ and accompanying text. 
on the same basis as U.S. citizens. ${ }^{156}$ Evenhandedness should also be the policy in the context of service of process and discovery.

The federal courts should not be agents for foreign policy decisions, even indirectly through rules of procedure. Foreign policymaking is a role for Gongress and the President. The reluctance of the courts to assume such a role is reflected in their deference to the executive on public-law issues, such as continued viability of a treaty under international law, ${ }^{157}$ refusal to entertain suits by unrecognized governments, ${ }^{158}$ reluctance to entertain litigation charged with international sensitivity, ${ }^{159}$ or their attempt to be evenhanded under announced executive policy. ${ }^{160}$ Congress can legislate in the field, as it did in 1964 for service and evidence in international litigation, ${ }^{161}$ in 1976 for foreign sovereign immunity, ${ }^{162}$ and in 1983 for Federal Rule of Civil Procedure $4 .{ }^{163}$ If there is to be any picking and choosing of policy with respect to a whole class of litigants (non-U.S. defendants in transnational civil litigation in the federal courts), Congress should be the decisionmaker. The courts, employing the currently used factoral approach, can make individualized decisions on how (and whether) a foreign defendant should be served, discovered, deposed, or sanctioned for failure to comply with the rules. ${ }^{164}$ The proposed amendments

156. See, e.g., Agreement on Trade Relations, Apr. 12, 1990, Czech.-U.S., art. 14(1), H.R. DoC. No. 231, 101st Cong., 2d. Sess. 23-24 (1990), 29 I.L.M. 902, 911. (1990); Irish Nat'l Ins. Co. v. Aer Lingus Teoranta, 739 F.2d 90, 91-92 (2d Cir. 1984); Robert R. Wilson, Access-to-Courts Provisions in United States Commercial Treaties, 47 AM. J. INT'L L. 20 (1953) (seeing the right as a matter of customary law).

157. See supra note 19.

158. Banco Nacional de Cuba v. Sabbatino, 376 U.S. 398, 410-11 (1964) (dictum); Guaranty Trust Co. v. United States, 304 U.S. 126, 137-41 (1938); RESTATEMENT (THIRD), supra note 10, $\S 204$. But see National Petrochem. Co. of Iran v. M/T Stolt Sheaf, 860 F.2d 551 (2d Cir. 1988), cert. denied, 486 U.S. 1081 (1989) (agency of nonrecognized government may sue where U.S. amicus brief urged such), and compare with Republic of Vietnam v. Pfizer Inc., 556 F.2d 892 (8th Cir. 1977).

159. See supra notes $40-43$ and accompanying text.

160. Consider, for example, foreign sovereign immunity after the Tate Letter and before the 1976 Act. See supra note 43. Professor Oxman adds that because the federal government may be unable or reluctant to intervene in private litigation on behalf of a foreign state, courts "must be particularly careful to avoid creating international conflict in the first place." Oxman, supra note 121, at 748 . If this is true for judicial decisionmaking in a particular case, it is a fortiori true and wise policy for rule drafting, which can affect many cases.

161. See 28 U.S.C. $\& 1696$ (service of process from foreign or international tribunals or persons within a district); id. $\S 1741$ (authentication of official records or documents of a foreign country); id. $\S 1781$ (transmittal of letters rogatory); id. $\S 1782$ (assistance to foreign or international tribunal seeking letter rogatory or request); id. $\S \S 1783-1784$ (subpoena of U.S. nationals in foreign country, contempt). A treaty can, of course, be amended by a protocol, as Andreas F. Lowenfeld has recommended for the Hague Evidence Convention, supra note 25. Andreas F. Lowenfeld, Introduction: Discovering Discovery, International Style, 16 N.Y.U. J. INT'L L. \& POL. 957, 959 (1984).

162. See supra notes $39-41$ and accompanying text.

163. Indeed, Congress must legislate for a service rule, unless it wishes to leave development of a rule to the process under the Rules Enabling Act, 28 U.S.C. \$ 2072. The federal courts cannot sua sponte create such a rule. Omni Capital Int'l v. Rudolf Wolff \& Co., 484 U.S. 97, 105-08 (1987).

164. See supra notes 51-54 and accompanying text. There is another, and more subtle, reason for carefully crafted legislation. Under the later-in-time rule, supra note 16 , a new federal statute would supersede conflicting treaty provisions, whether bilateral-such as the Agreement on Trade Relations, supra note 156 - or multilateral, for example, the Hague Service and Evidence Conventions, supra note 25. This may be helpful in the fluid state succession situation in Eastern Europe and elsewhere. Besides bilateral agreements such as the Agreement on Trade Relations with the former Czechoslovakia, supra note 156, the Hague Service and Evidence Conventions, supra note 25 , may be on dubious 
to Rule 4 regarding waiver of service of process, even without the potential for costs assessment, and those for mail service, have the potential for intrusion, perhaps inadvertently, into the foreign policy process of the United States. As in the case of the discarded amendments for Rules 26 and 28, Rule 4 should be redrafted to take positive account of U.S. treaty obligations, other sources of international law, and the claims of other sovereign states.

The courts should not be in the business of promulgating rules of procedure which, in a given context, can intrude extensively into the realm of foreign relations, an arena that is primarily a presidential or congressional preserve under the Constitution.

grounds as they apply to the Czech Republic, Slovakia, and Germany. The status of the Arbitration Convention, supra note 25, may be doubtful as it applies to the former Czechoslovakia, the former USSR, and the former Yugoslavia. See UNITED STATES DEPARTMENT OF STATE, TREATIES IN FORCE 290, 351-52 (1993); George K. Walker, Integration and Disintegration in Europe: Reordering the Treaty Map of the Continent, 6 TRANSNAT'L LAW. 1 (1993); Symposium, State Succession in the Former Soviet Union and in Eastern Europe, 33 VA. J. INT'L L. 253 (1993). Carefully crafted federal législation may help with treaty succession problems; in this regard, congressional committees would be well advised to consult with appropriate counsel in the Office of the Legal Adviser of the Department of State before draft legislation goes forward. 